\title{
Dendroclimatic responses of four European broadleaved tree species near their south- western range edges
}

\author{
Received: 30 September 2016; Accepted: 28 December 2016
}

\begin{abstract}
Iberian temperate forests are distributed along the boundary between the Atlantic and the Mediterranean biogeographical regions, and represent the south-western range edges of diverse European broadleaved deciduous tree species. Trees growing at the boundary between Atlantic and Mediterranean biomes suffer from different stresses, including increasing moisture deficit which has been identified as one of the main limitations for growth. In this work, dendrochronological techniques were employed to characterize the radial growth of Acer campestre L., Fagus sylvatica L., Fraxinus excelsior L., and Quercus robur L. in a mixed forest in northern Spain, and examine its relationships with local climate near their south-western range edges. Acer and Fagus tree-ring chronologies showed the highest common signal and the strongest responses to climate. Positive effects of precipitation, especially in the previous December and current summer, were relevant for growth of all species. Only Acer growth showed a detrimental effect of maximum diurnal temperatures in the previous autumn and current summer, while Fraxinus and Quercus growth was benefited by above-average winter temperatures. Cloud cover strongly improved the radial growth of all species, probably because cloudy conditions mitigate the detrimental effects of summer water depletion and low winter temperatures. The beneficial effects of precipitation and cloudiness on tree growth were temporally unstable and have become significant generally since the 1970s, suggesting that rising temperatures and decreasing rainfall shape radial growth-climate relationships of broadleaved deciduous trees near their southern range edges.
\end{abstract}

Keywords: Acer campestre, Fagus sylvatica, Fraxinus excelsior, Quercus robur, dendrochronology

Address: V. Rozas, J. M. Olano, Área de Botánica, Departamento de Ciencias Agroforestales, Universidad de Valladolid, Campus Duques de Soria, 42004 Soria, Spain, e-mail: vicenterozas@gmail.com

\section{Introduction}

Climatic predictions forecast a trend to increasing moisture deficit during the warm season at the boundary between Atlantic and Mediterranean biomes in southern Europe (IPCC, 2014). Process-based models predict that Mediterranean ecosystems will experience an important decrease of water availability, with a severe impact on hydrological and carbon cycles, vegetation dynamics and productivity, and biodiversity (Sala et al., 2000; Anav \& Mariotti, 2011; Santini et al., 2014). Even if some tree species show adaptive capacities for drought tolerance (Bolte et al., 2016; Cocozza et al., 2016), the impact of climate 
change on forest vitality and tree growth is likely to occur first at the boundary of a species range, where limiting conditions occur more frequently than at core range (Nahm et al., 2006). In this sense, the Iberian Peninsula is a very sensitive territory where many temperate tree species reach their south-western range edge, being progressively replaced by more drought-tolerant species adapted to Mediterranean conditions (Sánchez de Dios et al., 2009). (a)

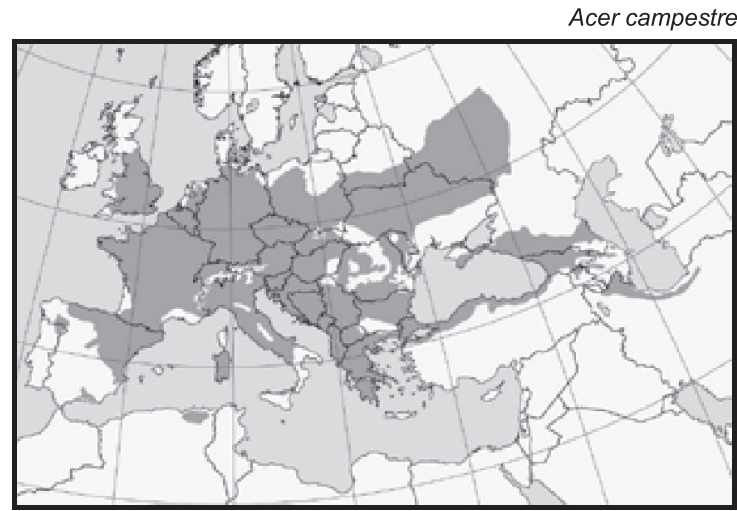

Fraxinus excelsio

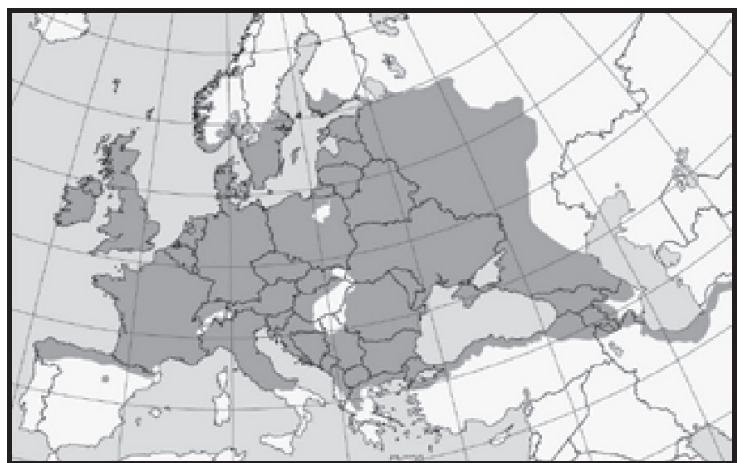

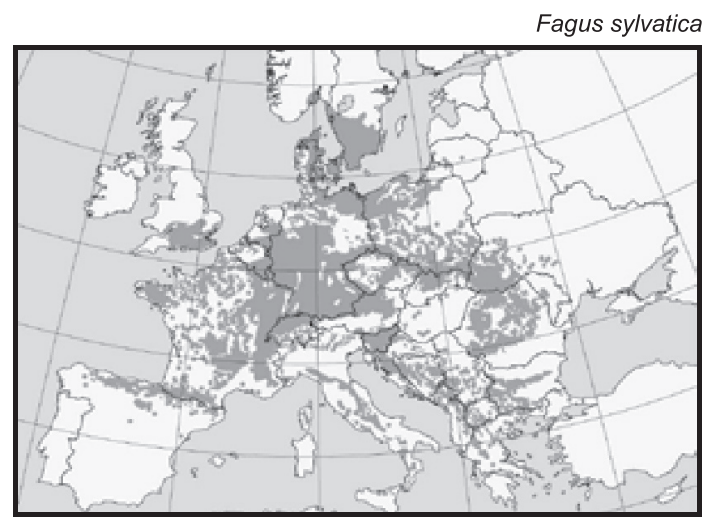

Quercus robur

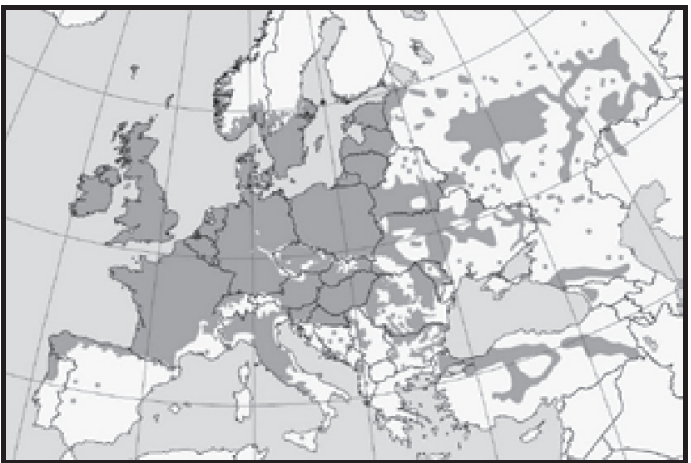

(b)
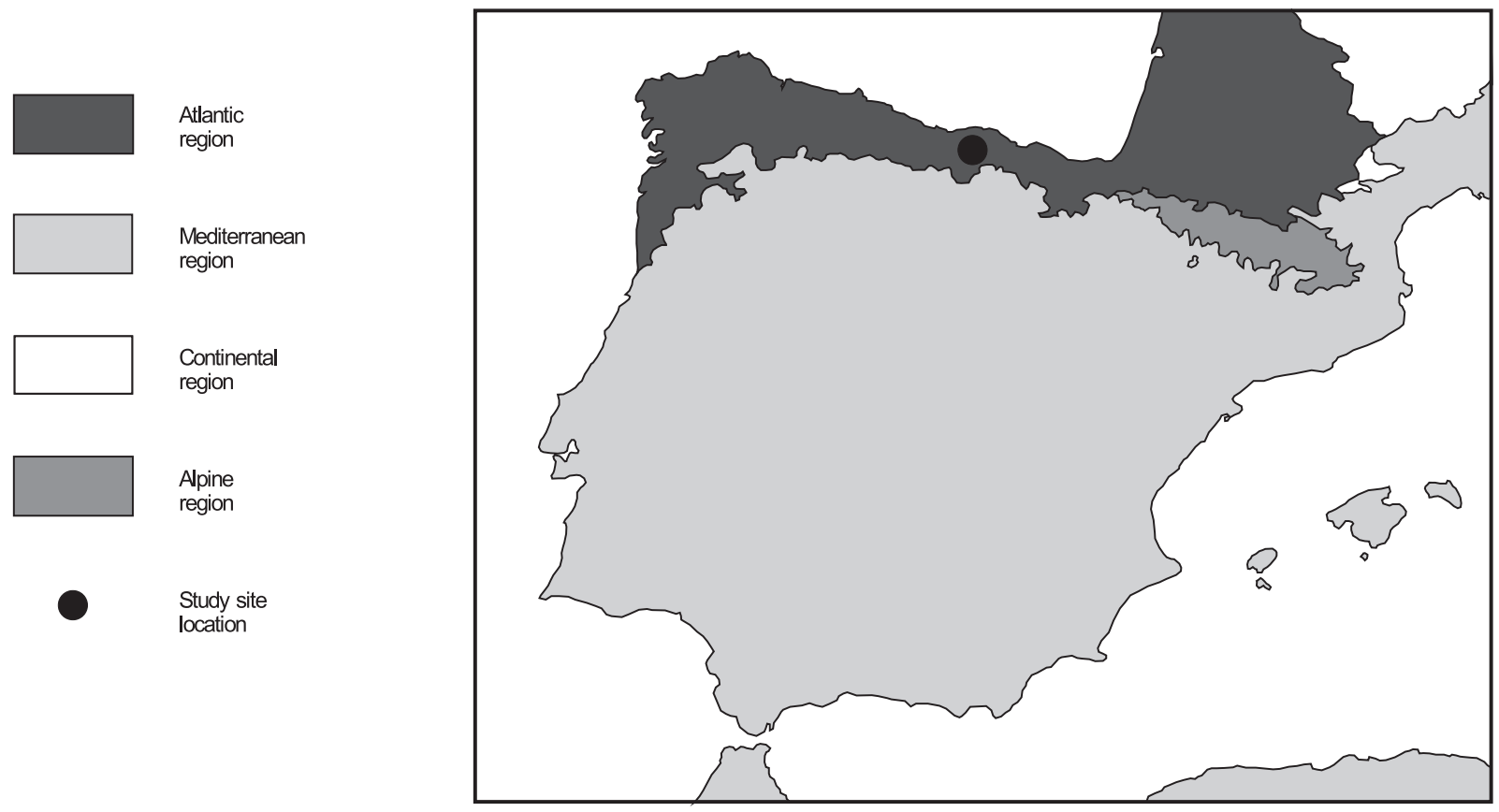

Fig. 1. Distribution ranges of the four studied species of broadleaved trees, obtained from the European Forest Genetic Resources Programme (http://www.euforgen.org/distribution-maps/) (a). Biogeographical regions of southwestern Europe, obtained from the European Environment Agency (http://www.eea.europa.eu/data-and-maps/data/biogeographical-regions-europe), and location of the study site within the Atlantic region in northern Iberian Peninsula (b) 
Summer drought is one of the main limitations for tree growth at the boundary between Atlantic and Mediterranean biomes (Rozas, 2005; Čufar et al., 2014; Čater \& Levanič, 2015; Rozas et al., 2015). However, higher water demand, caused by a reduction in rainfall or an increase in temperature, is not the only climatic stress for trees growing near their range edges. Temperate trees suffer from additional stress sources at the transitional areas between Atlantic and Mediterranean regions revealing a more complex picture (González-González et al., 2014). For example, high levels of precipitation combined with relatively high winter temperatures has been shown to be the main cause for growth reduction and dieback of $Q$. robur in the north-western Iberian Peninsula (Rozas \& García-González, 2012). Analyses of F. sylvatica tree-ring chronologies from south-western Europe have shown that spring temperature, together with the amount of winter precipitation, coexist with water availability in summer as major drivers of radial growth (Lebourgeois et al., 2005; Piovesan et al., 2005). In addition, it has been recently demonstrated that the dependency of $F$. sylvatica growth on drought stress is mitigated by cloudiness near its Iberian range edge, and that this alleviating effect has intensified in the last decades (Rozas et al., 2015).

Dominant species such as F. sylvatica and $Q$. robur have been studied in detail throughout Europe, with investigations of climate-to-growth relationships based on extensive networks of tree-ring chronologies (Lebourgeois et al., 2005; Piovesan et al., 2005; Scharnweber et al., 2011; Čufar et al., 2014; Čater \& Levanič, 2015; Rozas et al., 2015). However, knowledge on the dendroclimatic response of other broadleaved European tree species is currently scarce (e.g., García-Suárez et al., 2009), even though they are vital components of temperate forest diversity.
In order to fill this gap, we used dendrochronological techniques to evaluate the sensitivity of tree-ring growth to limiting climatic factors in four deciduous broadleaved tree species, Acer campestre L., Fagus sylvatica L., Fraxinus excelsior L., and Quercus robur L., coexisting in a mixed forest near their south-western range edges in northern Spain. These species are widely distributed over temperate deciduous forests in Europe, and reach their south-western distribution limits in the northern Iberian Peninsula (Fig. 1a). Two main questions were tested: (1) whether radial growth was sensitive to ongoing warming and drying trends near the boundary between Atlantic and Mediterranean biomes, and (2) whether this sensitivity differed among the four species over the last decades.

\section{Materials and Methods}

\section{Study site}

The study site is a mature Pyreneo-Cantabrian Quercus-Fraxinus forest (EUNIS habitat type G1.A19; http://eunis.eea.europa.eu/habitats/1116; Davies et al., 2004). This species-rich forest type has been historically cleared in northern Spain for cultivation and pasture establishment on their fertile soils. As a result, stands including mature trees are extremely rare. The forest is located on a hilly area in San Felices de Buelna municipality, Cantabria, Spain (N 4314'38”, W 04 $\left.00^{\prime} 34^{\prime \prime}\right)$, at an elevation of $520 \mathrm{~m}$ within the Atlantic biogeographical region (Fig. 1b). Dominant tree species are Quercus robur, Fagus sylvatica, Fraxinus excelsior, Acer campestre and, to a lesser extent, Ulmus glabra Huds. and Taxus baccata L. The understorey is composed of Corylus avellana L., Ilex aquifolium L.,
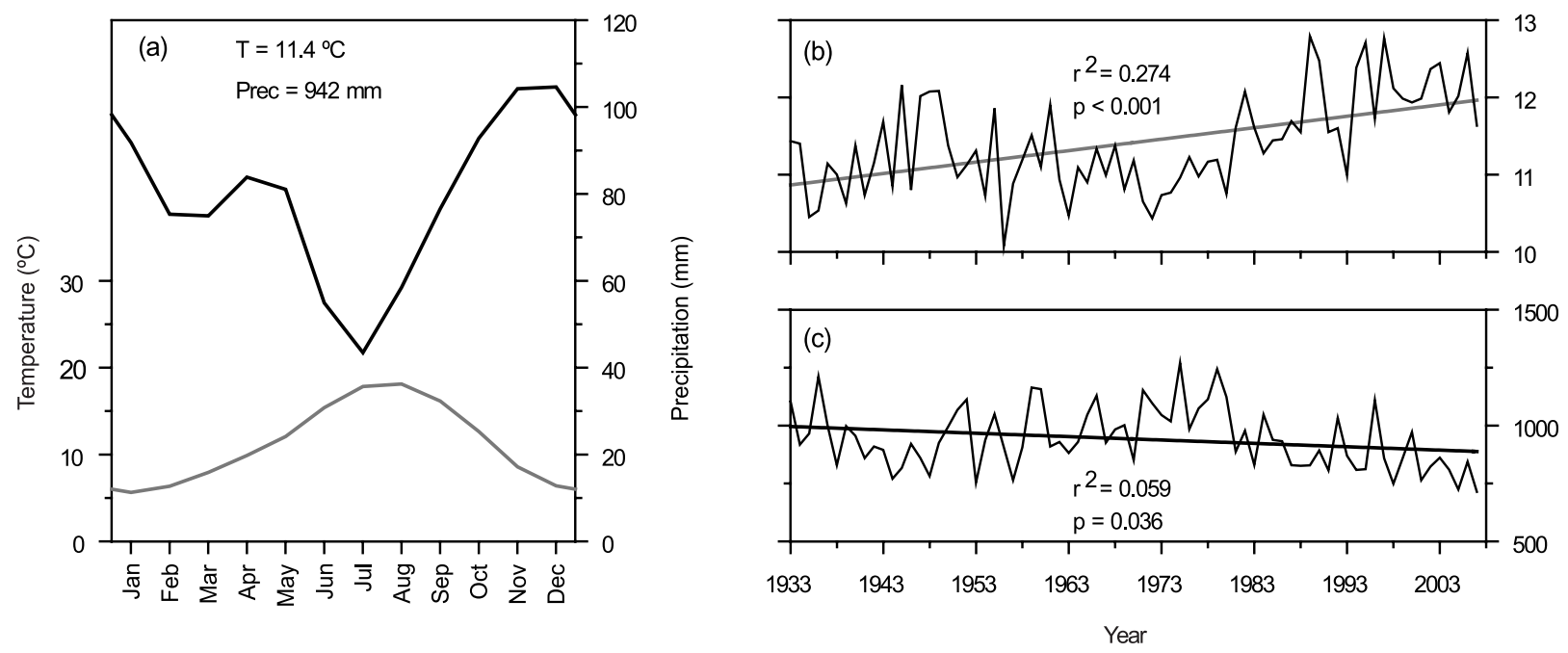

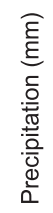

Fig. 2. Climatic diagram of the study site showing mean annual temperature (T) and annual precipitation (Prec) in the period 1933-2007 (a). Temporal variation of mean annual temperature (b) and total annual precipitation (c). Linear fits, coefficients of determination $\left(r^{2}\right)$ and their statistical significances (p) are shown in (b) and (c) 
Crataegus monogyna Jacq. and a variety of ferns, climbers and herbaceous plants typical of eutrophic soils. Soil is mainly deep brown on Cretaceous limestone, but areas of shallow soil and exposed bedrock exist.

The climate of the study site is temperate Atlantic, with the minimum precipitation and maximum temperature occurring over summer (Fig. 2a). Mean annual temperature is $11.4{ }^{\circ} \mathrm{C}$ but a significant rising trend is evident in 1933-2007, particularly since the 1970s (Fig. 2b). Mean annual precipitation is 942 $\mathrm{mm}$ with a slightly decreasing trend in 1933-2007 (Fig. 2c).

\section{Sampling and sample processing}

Twenty dominant or co-dominant trees per species were selected for sampling. Bole diameter at breast height $(\mathrm{DBH})$ was registered for each tree and two wood cores per tree were collected along opposing radii using increment borers. Wood cores were air dried, glued onto wooden mounts, surfaced and polished until the xylem cellular structure was visible in a transverse section. Tree-ring series along the cores were dated under magnification by assigning calendar years to the rings through the identification of characteristic ring sequences. Tree ring boundaries were easily identified in the ring-porous wood of Fraxinus and Quercus, and in general also in the diffuse-porous wood of Acer and Fagus. However, cores from two Acer trees showed some undifferentiated tree-ring boundaries and the samples were discarded. Total ring widths were measured to the nearest $0.001 \mathrm{~mm}$ using a stereomicroscope and a Velmex sliding-stage micrometer interfaced with a computer. The program COFECHA (Grissino-Mayer, 2001) was used to quantitatively check for potential cross-dating errors. Tree age at coring height was individually estimated based on the oldest core per tree.

\section{Radial growth assessment and chronologies calculation}

$\mathrm{DBH}$, tree age and mean ring width were statistically compared among species by means of the non-parametric Kruskal-Wallis test. The statistical relationships of tree-ring growth to climate were calculated based on detrended and standardized tree-ring chronologies. Every ring width series was standardized with the ARSTAN software (Cook \& Holmes, 1996), following a two-step procedure. The series were first fitted to a linear or negative exponential function to remove long-term ontogenetic trends, and the indices were calculated by dividing each measured width by its expected value, according to the fitted function. Secondly, the obtained residuals were fitted to a spline function with a $50 \%$ frequency response of 32 years, which was flexible enough to maximize the high-frequency climatic information. All growth indices from each species were averaged on an annual basis into a whole chronology per species using a biweight robust mean.

The reliable portion of each chronology was the period covered with series from at least five trees. The statistical quality of the chronologies was assessed for 1933-2007, the common period with at least five trees in all the chronologies. The statistical quality of the chronologies was assessed using standard basic statistics (Fritts, 2001), which were calculated with the ARSTAN software. These statistics were the mean sensitivity (MS), or mean relative change between consecutive ring widths, the signalto-noise ratio (SNR), or strength of the observed common signal among trees, the mean between-trees correlation (RBT), or mean value of all possible correlations between trees, and the expressed population signal (EPS), or degree to which the obtained chronology represents the theoretically perfect chronology. Common patterns of growth behavior among tree-ring chronologies were explored using $t$-test and two-tailed Pearson correlation for the common period 1933-2007. Correlations and Kruskal-Wallis tests were calculated with the software SPSS v. 15.0 (SPSS Inc., Chicago IL, USA).

\section{Computing tree-ring growth responses to climate}

The climatic data used in this study were monthly gridded time series for maximum mean temperatures $\left(\mathrm{Tmax},{ }^{\circ} \mathrm{C}\right)$, total precipitation (Prec, $\mathrm{mm}$ ), and cloud fraction (Cld, \%) obtained from the CRU TS 3 data set for the period 1901-2009 (Mitchell \& Jones, 2005). CRU climate time series were taken from the Climate Explorer of the Royal Netherlands Meteorological Institute dataset (http://climexp.knmi.nl/) for the $43-43.5^{\circ}$ north latitude, $4-4.5^{\circ}$ west longitude sector that included the study site. The temporal window for climatic predictors was taken from June of the year prior to ring formation $\operatorname{Jun}(-1))$ to September of the year of ring formation (Sep).

Pearson's correlations and multiple regression models were used to estimate the response of the standardized chronologies to monthly and bimonthly climate time series, considering the common period 1933-2007. In order to search for species-specific patterns in the climatic responses, a principal component analysis (PCA) on the standardized chronologies and the significant climatic variables was performed for the common period 1933-2007. The PCA was performed using a Varimax rotation procedure, based on the two-tailed correlation matrix among tree-ring chronologies and climatic variables. Moving Pearson 
correlations were also calculated, at intervals of 35-yr width and shifted year-by-year, to assess the temporal consistency of tree-ring growth-to-climate relationships. The moving correlations were calculated between the tree-ring chronologies for the four tree species, and the main climatic variables influencing growth, as revealed by multiple regression models.

\section{Results}

Mean DBHs of Fagus and Quercus were larger than those of Acer and Fraxinus $\left(\chi^{2}=35.44, \mathrm{p}<0.001\right.$,
Kruskal-Wallis test). The oldest trees were Quercus, with a mean and a maximum age of 141 and $193 \mathrm{yr}$, respectively, while Fagus and Fraxinus were youngest on average $\left(\chi^{2}=45.41, \mathrm{p}<0.001\right)$, with over 70 yr. Acer showed an intermediate mean age of $89 \mathrm{yr}$ (Table 1). Mean ring width was largest for Fagus and smallest for Quercus, while Acer and Fraxinus showed intermediate values $\left(\chi^{2}=51.95, \mathrm{p}<0.001\right)$.

The four indexed tree-ring chronologies (Fig. 3) were significantly inter-correlated in the common period 1933-2007, with Acer and Fagus showing the highest similitude, and Quercus and Fraxinus the lowest similitude (Table 2). Indexed chronologies

Table 1. Size, age, and tree-ring growth traits of the sampled trees, and indicators of statistical quality for the standardized tree-ring chronologies of Acer campestre, Fagus sylvatica, Fraxinus excelsior and Quercus robur. DBH: bole diameter at $1.3 \mathrm{~m}$ above ground level. Means with different letters are significantly different $(\mathrm{p}<0.05)$, according to Kruskal-Wallis test

\begin{tabular}{lcccc}
\hline & Acer & Fagus & Fraxinus & Quercus \\
\hline Mean DBH \pm SD (cm) & $49.2 \pm 9.9 \mathrm{a}$ & $71.3 \pm 11.1 \mathrm{~b}$ & $49.6 \pm 13.0 \mathrm{a}$ & $67.6 \pm 12.3 \mathrm{~b}$ \\
Mean age \pm SD (yr) & $89 \pm 15 \mathrm{~b}$ & $70 \pm 28 \mathrm{a}$ & $71 \pm 22 \mathrm{a}$ & $141 \pm 21 \mathrm{c}$ \\
Maximum age (yr) & 122 & 130 & 157 & 193 \\
Mean ring width \pm SD (mm) ${ }^{a}$ & $2.8 \pm 0.4 \mathrm{~b}$ & $4.8 \pm 1.0 \mathrm{c}$ & $3.5 \pm 1.2 \mathrm{~b}$ & $1.7 \pm 0.7 \mathrm{a}$ \\
T/C & $18 / 34$ & $20 / 34$ & $20 / 35$ & $20 / 38$ \\
MS $^{\text {a b }}$ & 0.254 & 0.193 & 0.182 & 0.261 \\
SNR $_{\text {a b }}$ & 10.28 & 17.68 & 7.93 & 6.76 \\
RBT & 0.391 & 0.469 & 0.306 & 0.326 \\
EPS a & 0.911 & 0.946 & 0.888 & 0.871 \\
\hline
\end{tabular}

a Calculated in the common period 1933-2007.

${ }^{\mathrm{b}} \mathrm{T} / \mathrm{C}$ : number of trees/cores in the chronology. MS: mean sensitivity. SNR: signal-to-noise ratio. RBT: mean between-trees correlation. EPS: expressed population signal.

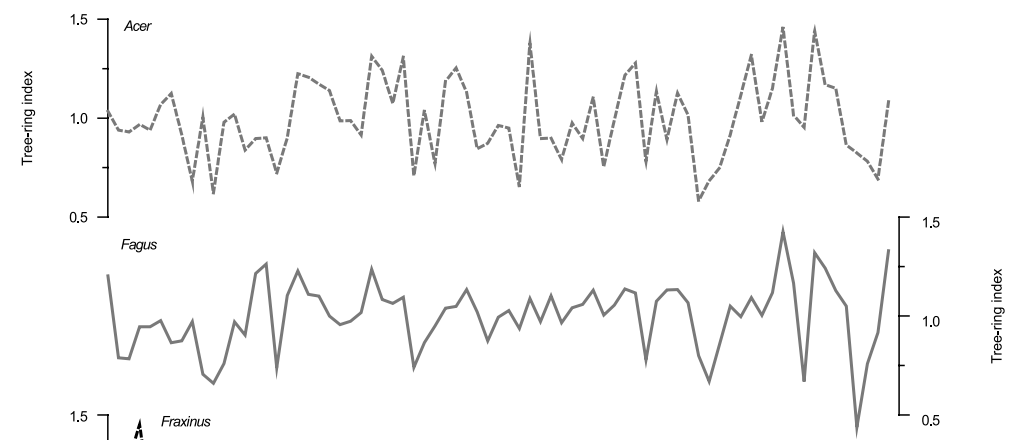
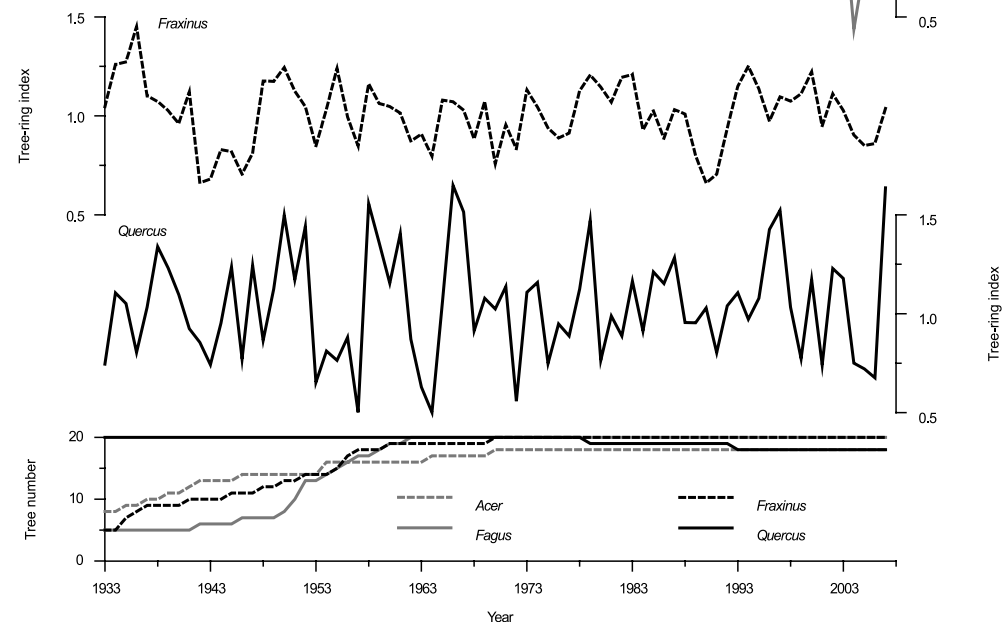

Fig. 3. Standardized tree-ring chronologies from total ring widths of the four study species, along with the temporal variation of tree sample replication, in the period 1933-2007 
Table 2. Matrix of $t$ values and two-tailed Pearson's correlations among standardized tree-ring chronologies in the period 1933-2007. Upper-right half of the matrix shows $t$ values, lower-left half shows correlation coefficients with their statistical significances. ${ }^{* *} \mathrm{p}<0.01$; ${ }^{* * *} \mathrm{p}<$ 0.001

\begin{tabular}{lcccc}
\hline & Acer & Fagus & Fraxinus & Quercus \\
\hline Acer & & 6.913 & 4.439 & 5.201 \\
Fagus & $0.629^{* * *}$ & & 3.318 & 4.246 \\
Fraxinus & $0.461^{* * *}$ & $0.362^{* *}$ & & 3.255 \\
Quercus & $0.520^{* * *}$ & $0.445^{* * *}$ & $0.356^{* *}$ & \\
\hline
\end{tabular}

from all the tree species showed adequate statistical quality. MS values ranged $0.182-0.261$, SNR values ranged 6.76-17.68, RBT values ranged 0.306-0.469, and EPS values ranged 0.871-0.946, which suggest an appropriate replication and a robust common signal for all studied species. According to the observed SNR and EPS statistics, Quercus and Fagus showed the lowest and the highest strength of the common signal, respectively, while Fraxinus and Acer showed intermediate values (Table 1).

Acer growth showed a detrimental effect of elevated Tmax in the previous September and October, and current July, while growth of Fraxinus, Quercus and Fagus showed a positive response to Tmax in January, February and March, respectively (Fig. 4a). With regard to precipitation, growth of all four species showed a positive response to previous December rainfall (Fig. 4b). In addition, Acer showed a positive response to July and August, and Fagus and Fraxinus responded positively to July precipitation. Cloud cover showed a positive correlation with Acer growth in February, May and August, with Fagus growth in February, May-June and August, with Fraxinus growth in previous July and May, and with Quercus growth in August (Fig. 4c).

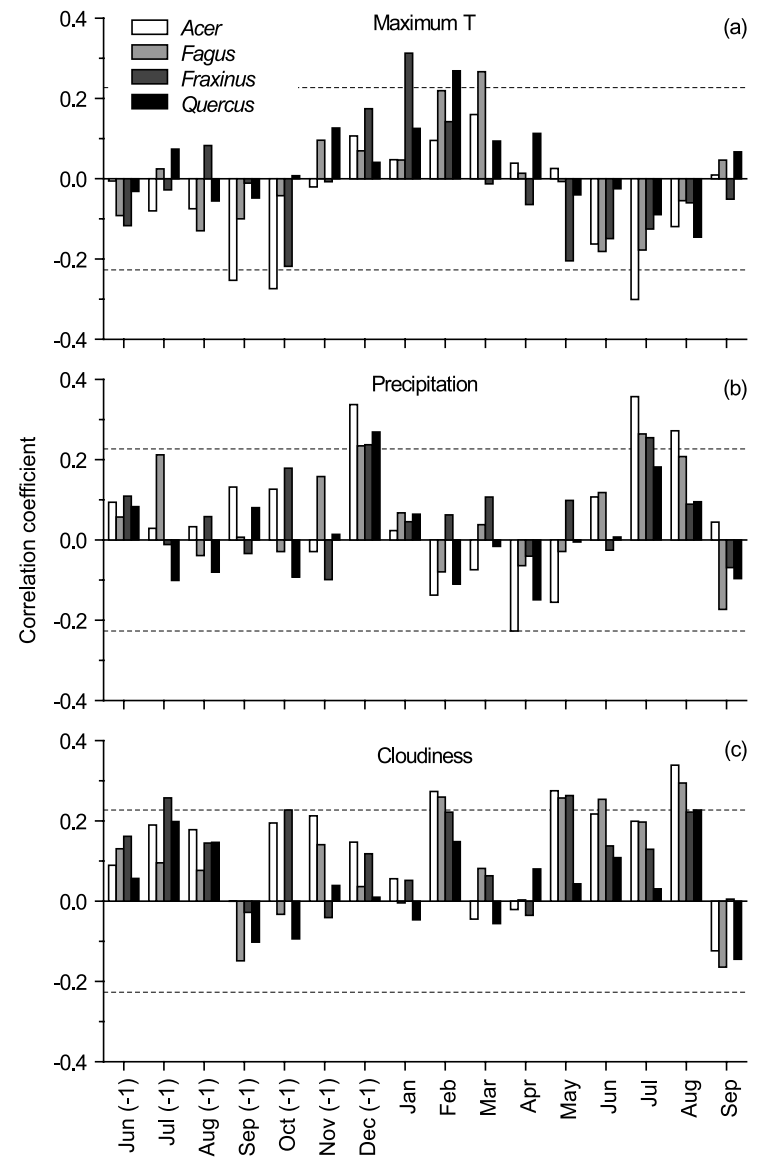

Fig. 4. Correlations between standardized tree-ring width chronologies from every tree species, and monthly climate time series of maximum temperature (a), precipitation (b) and cloud cover (c), in the period 1933-2007. Correlations outside the dashed lines are statistically significant $(p<0.05)$. $(-1)$ indicates the year previous to growth

Table 3. Linear regression models for monthly and bimonthly climatic predictors significantly related to tree-ring growth of Acer campestre, Fagus sylvatica, Fraxinus excelsior and Quercus robur in the period 1933-2007

\begin{tabular}{|c|c|c|c|c|c|c|}
\hline & Model $F$ & Model $p$ & Predictor $^{\mathrm{a}}$ & $\beta$ & $\mathrm{t}$ & $\mathrm{p}$ \\
\hline \multirow{4}{*}{ Acer } & \multirow{4}{*}{8.99} & \multirow{4}{*}{$<0.001$} & Prec JulAug & 0.306 & 3.08 & 0.002 \\
\hline & & & $\operatorname{Prec} \operatorname{Dec}(-1)$ & 0.240 & 2.41 & 0.018 \\
\hline & & & Tmax SepOct $(-1)$ & -0.229 & -2.27 & 0.026 \\
\hline & & & Cld Aug & 0.208 & 2.12 & 0.037 \\
\hline \multirow{3}{*}{ Fagus } & \multirow{3}{*}{7.93} & \multirow{3}{*}{$<0.001$} & Cld Aug & 0.336 & 3.21 & 0.002 \\
\hline & & & Prec Jul & 0.276 & 2.46 & 0.016 \\
\hline & & & Cld MayJun & 0.246 & 2.24 & 0.028 \\
\hline \multirow{4}{*}{ Fraxinus } & \multirow{4}{*}{6.96} & \multirow{4}{*}{$<0.001$} & Tmax Jan & 0.325 & 3.16 & 0.002 \\
\hline & & & Prec Jul & 0.274 & 2.65 & 0.009 \\
\hline & & & Cld May & 0.218 & 2.13 & 0.036 \\
\hline & & & Cld Jul(-1) & 0.216 & 2.11 & 0.038 \\
\hline \multirow{3}{*}{ Quercus } & \multirow{3}{*}{5.92} & \multirow{3}{*}{0.001} & Tmax Feb & 0.309 & 2.88 & 0.005 \\
\hline & & & $\operatorname{Prec} \operatorname{Dec}(-1)$ & 0.235 & 2.18 & 0.032 \\
\hline & & & Cld Aug & 0.237 & 2.18 & 0.032 \\
\hline
\end{tabular}

${ }^{a}$ Prec: precipitation, Tmax: maximum temperature, Cld: cloudiness, (-1): year previous to growth. 
According to linear regression models, Acer growth was a direct function of precipitation in July-August and the previous December, an inverse function of Tmax in the previous September-October, and a direct function of August cloudiness (Table 3). Cloud cover in August and May-June also showed a beneficial effect on Fagus growth, together with July precipitation. Growth of Fraxinus was directly related to January Tmax, July precipitation, and cloud cover in May and the previous July. Finally, radial growth of Quercus was a linear function of February Tmax, precipitation in the previous December, and August cloud cover.

The PCA biplot revealed two main pattern of climatic response (Fig. 5): (1) Fraxinus and Quercus chronologies were mostly linked to positive responses to maximum temperatures in January and February, previous December precipitation and previous July cloudiness, and (2) Acer and Fagus chronologies were mostly linked to positive responses to precipitation and cloudiness in late spring and summer, and to a negative response to maximum temperatures in previous September-October.

Responses to the main climatic factors controlling tree-ring growth were, for the most part, unstable through time. Positive responses of Acer growth to

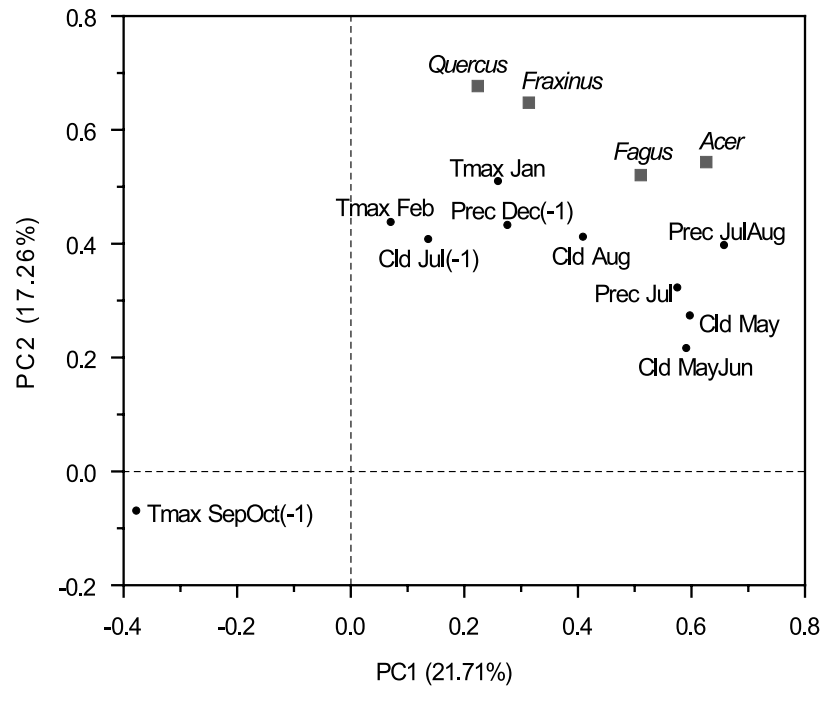

Fig. 5. Principal component analysis biplot on the standardized tree-ring chronologies for the four studied species (grey squares) and the significant climatic variables (black symbols), for the common period 1933-2007. The percentage of variance explained by every principal component (PC1 and PC2) is shown. (-1) indicates the year previous to growth
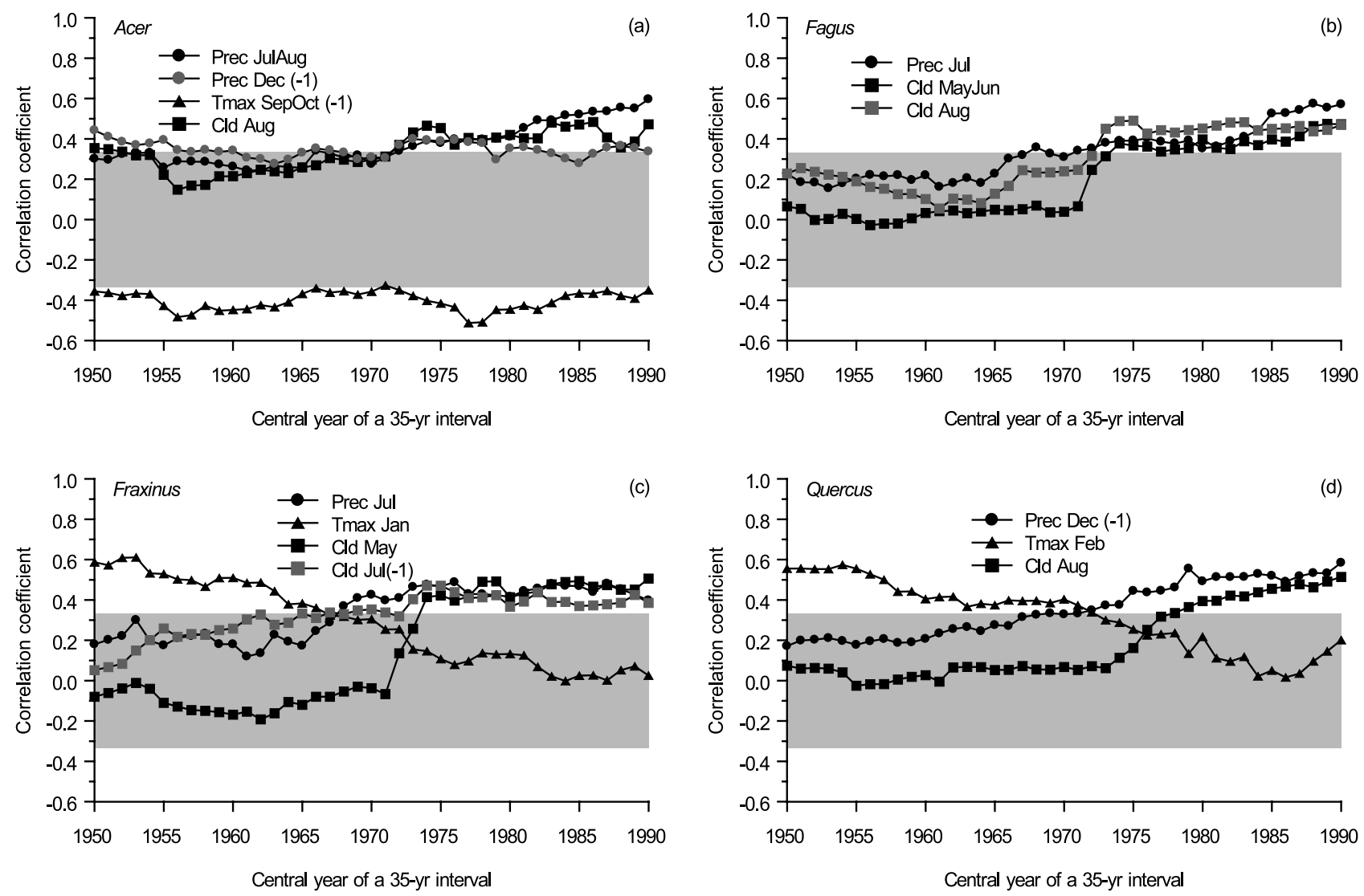

Fig. 6. Temporal variation of moving correlations between the variation of Acer campestre (a), Fagus sylvatica (b), Fraxinus excelsior (c), and Quercus robur (d) standardized tree-ring width chronologies, and the main climatic factors controlling radial growth. Correlations were calculated in 35-year intervals, and lagged by 1 year. Correlations outside the shaded areas are statistically significant $(\mathrm{p}<0.05) .(-1)$ indicates the year previous to growth 
July-August precipitation and August cloudiness were significant since the 1970s, while the negative relationship with Tmax in the previous September-October was significant throughout the whole study period (Fig. 6a). Positive relationships of $\mathrm{Fa}$ gus growth with July precipitation and cloud cover in May-June and August were significant since the early 1970s only (Fig. 6b). Positive effect of January Tmax on Fraxinus growth was significant up to the late 1960s, and since that date the positive effect of July precipitation become significant, while cloudiness in May and previous July showed a positive effect on growth since the mid 1970s (Fig. 6c). In the case of Quercus growth, the beneficial effects of previous December precipitation and August cloudiness were significant since the 1970s, but the positive effect of February Tmax were significant up to the early 1970s (Fig. 6d).

\section{Discussion}

Water balance during the growing season was the most influential factor determining secondary growth in deciduous species near the Atlantic-Mediterranean boundary. Water limitations have increased during the last decades due to warmer and drier climate conditions, whereas the constraining role of winter temperature has decreased. Factors constraining secondary growth showed interspecific agreement, but also a species-level discrepancy in their tolerance to summer drought and winter frost.

A positive response to summer rainfall has been evidenced for a variety of broadleaved species from temperate forests in Europe (García-Suarez et al., 2009; Scharnweber et al., 2011; Čufar et al., 2014; Garamszegi \& Kern, 2014; Rozas et al., 2015) and North America (Tardif et al., 2001; Bishop et al., 2015). Accordingly, summer rainfall in July-August controlled radial growth of Acer, Fagus and Fraxinus. The absence of a beneficial signal of summer rainfall in Quercus radial growth might reflect its higher drought-tolerance (Niinemets \& Valladares, 2006). Even if summer drought is usually intensified by higher temperatures, maximum summer temperatures did not negatively impact growth indices, suggesting that water stress was mainly due to insufficient precipitation, instead of increased evapotranspiration rates. The unique exception was Acer, whose growth was negatively impacted by elevated temperatures in the previous September-October and current July. The detrimental effect of high diurnal temperatures in the previous autumn on Acer growth was prevalent and stable over time. Acer campestre shows higher sap flux densities than other coexisting broadleaved trees (Gebauer et al., 2008), which suggests that this species would be particularly susceptible to water loss in summer by high transpiration rates under elevated diurnal temperatures.

According to our results, cloudiness improved tree-ring growth of the four broadleaved deciduous tree species. This suggests that cloud cover can largely mitigate the detrimental effects of summer water stress and low winter temperatures at the boundary between the Atlantic and the Mediterranean biomes. Cloudiness reduces the range between daily minimum and maximum temperatures (Karl et al., 1993), and moderates the evaporative demand in summer through increased atmospheric humidity plus attenuation of incoming solar radiation (Reinhardt \& Smith, 2008). Thus, cloudiness might largely have mitigated the detrimental effects of summer water stress, improving tree-ring growth of broadleaved deciduous trees in the study area. This finding agrees with the evidence that cloud cover improves growth of Fagus sylvatica populations in northern Spain (Rozas et al., 2015), and with the evidence of cloud-enhanced carbon uptake and ecosystem production in a temperate deciduous forest in North America (Min $\&$ Wang, 2008). Cloudiness reduces the amount of direct sunlight while increasing the diffuse solar radiation, which can improve photosynthetic activity and ecosystem productivity due to a more efficient penetration of radiation inside the forest canopy (Urban et al., 2007; Knohl \& Baldocchi, 2008).

Interestingly, radial growth of the four species also responded positively to precipitation in the previous December during winter arrest. A similar response has been documented for old-growth Quercus robur trees in northern Spain (Rozas, 2005), for Fagus sylvatica in the Italian peninsula (Piovesan et al., 2005), and for Fraxinus mandshurica in northeastern China (Gao et al., 2010). The positive effect of rainy December on subsequent tree growth was probably related to the recharge of soil water reserves in winter (Piovesan et al., 2005). December is the rainiest month in the study area and winter rainfall largely contributes to soil water recharge, decreasing the detrimental effect of water depletion during the growing season and favouring tree growth. Higher maximum temperatures in late winter-early spring, at the end of winter arrest, favoured growth of Fraxinus, Quercus and Fagus, but with the exact timing differing among species in January, February and March, respectively. Above-average winter temperatures reduce the probability of frost events and lead to reduced damage of buds and twigs of frost-sensitive species (Cedro \& Nowak, 2006). In addition, high winter temperatures may induce earlier initiation of earlywood formation and leaf flushing in ring-porous tree species, reducing the risk of embolism occurrence and increasing wood production (Barbaroux \& Bréda, 2002). The absence of a positive effect of winter temperatures on Acer and Fagus growth could be a consequence of 
their xylem anatomy. Acer and Fagus species show small to medium vessels, ranging 44-80 $\mu$ m diameter for Acer and 45-80 $\mu \mathrm{m}$ diameter for Fagus. In contrast, Fraxinus and Quercus species show large to very large vessels, ranging 54-345 $\mu \mathrm{m}$ diameter for Fraxinus and 130-420 $\mu \mathrm{m}$ diameter for Quercus (Richter \& Dallwitz, 2000). The risk of freezing-induced cavitation of vessels is proportional to its mean conduit diameter (Sperry et al., 2006), with the narrow vessels of the diffuse-porous trees being less susceptible to embolism caused by low winter temperatures than the large vessels of ring-porous trees (Davis et al., 1999).

The shift in the response of tree-ring growth to climate may respond to the changing climatic conditions in the study area. The positive effects of precipitation and cloudiness have increased, becoming significant after the 1970s, suggesting that their mitigating effects have appeared during the last decades as a response to enhanced drought stress due to rising temperatures and decreasing rainfall. In contrast, the positive effects of high temperatures in previous winter showed the opposite pattern, with decreasing influence on Fraxinus and Quercus growth, and significant effects disappearing in the 1960s-1970s. These results suggest a shift in the limiting factors for growth of these species. Prior to the 1970s, warm winters benefited tree growth, while in recent decades, under warmer and drier conditions, water availability has become the most limiting factor for growth. This interpretation supports previous evidences of a rising trend in the dependency of growth on summer precipitation for diverse broadleaved trees in Europe (García-Suárez et al., 2009; Garamszegi \& Kern, 2014; Čater \& Levanič, 2015), and particularly for Fagus sylvatica in northern Spain (Rozas et al., 2015).

This work emphasizes that growth of broadleaved trees was sensitive to climatic factors consistent with ongoing warming and drying trends near their southern range edges. Cloudiness and precipitation consistently favoured radial growth, while impacts of these and other climate variables vary temporally, with greater beneficial effects on tree growth since the 1970s. This study identified the climatic factors limiting radial growth of broadleaved trees near their south-western range edges. The temporal variability of growth-climate relationships highlights the potential effects of a drier and warmer future climate on tree growth. The importance of rainfall and cloudiness in promoting greater-than-expected growth is noteworthy and its temporal evolution should be considered in the conservation and management of temperate deciduous forests along the boundary between the Atlantic and the Mediterranean biogeographical regions.

\section{Acknowledgements}

The authors thank A. González, S. Lamas, and B. Rodríguez-Morales for field and laboratory assistance, Daniel Harris for English language editing, and the Service for Forest and Wildlife Conservation of Cantabria for sampling permission. This work was funded by Instituto Nacional de Investigación y Tecnología Agraria y Alimentaria (INIA), Spanish Government (project RTA2006-00117).

\section{References}

Anav A \& Mariotti A (2011) Sensitivity of natural vegetation to climate change in the Euro-Mediterranean area. Climate Research 46: 277-292.

Barbaroux C \& Bréda N (2002) Contrasting distribution and seasonal dynamics of carbohydrate reserves in stem wood of adult ring-porous sessile oak and diffuse-porous beech trees. Tree Physiology 22: 1201-1210.

Bishop DA, Beier CM, Pederson N, Lawrence GB, Stella JC \& Sullivan TJ (2015) Regional growth decline of sugar maple (Acer saccharum) and its potential causes. Ecosphere 6: 179.

Bolte A, Czajkowski T, Cocozza C, Tognetti R, de Miguel M, Pšidová E, Ditmarová L, Dinca L, Delzon S, Cochard H, Ræbild A, de Luis M, Cvjetkovic B, Heiri C \& Müller J (2016) Desiccation and mortality dynamics in seedlings of different European beech (Fagus sylvatica L.) populations under extreme drought conditions. Frontiers in Plant Science 7: 751.

Čater M \& Levanič T (2015) Physiological and growth response of Quercus robur in Slovenia. Dendrobiology 74: 3-12.

Cedro A \& Nowak G (2006) Effects of climatic conditions on annual tree ring growth of the Platanus $\times$ hispanica 'Acerifolia' under urban conditions of Szczecin. Dendrobiology 55: 11-17.

Cook ER \& Holmes RL (1996) Guide for computer program ARSTAN: The international tree ring data bank program library version 2.0 user's manual (ed. by HD Grissino-Mayer, RL Holmes \& HC Fritts) Laboratory of Tree-Ring Research, University of Arizona, Tucson, AZ, USA, pp. 75-87.

Cocozza C, de Miguel M, Pšidová E, Ditmarová L, Marino S, Maiuro L, Alvino A, Czajkowski T, Bolte A \& Tognetti R (2016) Variation in ecophysiological traits and drought tolerance of beech (Fagus sylvatica L.) seedlings from different populations. Frontiers in Plant Science 7: 886.

Čufar K, Grabner M, Morgós A, Martínez del Castillo E, Merela M \& de Luis M (2014) Common climatic signals affecting oak tree-ring growth in SE Central Europe. Trees 28: 1267-1277. 
Davies CE, Moss D \& Hill MO (2004) EUNIS Habitat Classification Revised 2004. Report to the European Topic Centre on Nature Protection and Biodiversity, European Environment Agency.

Davis SD, Sperry JS \& Hacke UG (1999) The relationship between xylem conduit diameter and cavitation caused by freezing. American Journal of Botany 86: 1367-1372.

Fritts HC (2001) Tree rings and climate. Blackburn Press, Caldwell.

Gao L, Zhang C, Zhao X \& Von Gadow K (2010) Gender-related climate response of radial growth in dioecious Fraxinus mandshurica trees. Tree-Ring Research 66: 105-112.

Garamszegi B \& Kern Z (2014) Climate influence on radial growth of Fagus sylvatica growing near the edge of its distribution in Bükk Mts., Hungary. Dendrobiology 72: 93-102.

García-Suárez AM, Butler CJ \& Baillie MGL (2009) Climate signal in tree-ring chronologies in a temperate climate: A multi-species approach. Dendrochronologia 27: 183-198.

Gebauer T, Horna V \& Leuschner C (2008) Variability in radial sap flux density patterns and sapwood area among seven co-occurring temperate broad-leaved tree species. Tree Physiology 28: 1821-1830.

González-González BD, Rozas V \& García-González I (2014) Earlywood vessels of the sub-mediterranean oak Quercus pyrenaica have greater plasticity and sensitivity than those of the temperate $Q$. petraea at the Atlantic-Mediterranean boundary. Trees 28: 237-252.

Grissino-Mayer HD (2001) Evaluating crossdating accuracy: A manual and tutorial for the computer program COFECHA. Tree-Ring Research 57: 205-221.

IPCC (2014) Climate change 2014: Impacts, Adaptation, and Vulnerability. Contribution of Working Group II to the Fifth Assessment Report of the Intergovernmental Panel on Climate Change. Cambridge University Press, Cambridge, UK.

Karl TR, Jones PD, Knight RW, Kukla G, Plummer N, Razuvayev V, Gallo KP, Lindseay J, Charlson RJ \& Peterson TC (1993) Asymmetric trends of daily maximum and minimum temperature. Bulletin of the American Meteorological Society 74: 1007-1023.

Knohl A \& Baldocchi DD (2008) Effects of diffuse radiation on canopy gas exchange processes in a forest ecosystem. Journal of Geophysical Research 113, G2. doi:10.1029/2007JG000663.

Lebourgeois F, Bréda N, Ulrich E \& Granier A (2005) Climate-tree-growth relationships of European beech (Fagus sylvatica L.) in the French Permanent Plot Network (RENECOFOR). Trees 19: 385-401.
Min Q \& Wang S (2008) Clouds modulate terrestrial carbon uptake in a midlatitude hardwood forest. Geophysical Research Letters 35. doi:10.1029/2007GL032398.

Mitchell TD \& Jones PD (2005) An improved method of constructing a database of monthly climate observations and associated high resolution grids. International Journal of Climatology 25: 693-712.

Nahm M, Radoglou K, Halyvopoulos G, Gessler A, Rennenberg H \& Fotelli MN (2006) Physiological performance of beech (Fagus sylvatica L.) at its Southeastern distribution limit in Europe: seasonal changes in nitrogen, carbon and water balance. Plant Biology 8: 52-63.

Niinemets U \& Valladares F (2006) Tolerance to shade, drought and waterlogging of temperate, Northern hemisphere trees and shrubs. Ecological Monographs 76: 521-547.

Piovesan G, Biondi F, Bernabei M, Di Filippo A \& Schirone B (2005) Spatial and altitudinal bioclimatic zones of the Italian peninsula identified from a beech (Fagus sylvatica L.) tree-ring network. Acta Oecologica 27: 197-210.

Reinhardt K \& Smith WK (2008) Impacts of cloud immersion on microclimate, photosynthesis and water relations of Abies fraseri (Pursh.) Poiret in a temperate mountain cloud forest. Oecologia 158: 229-238.

Richter HG \& Dallwitz MJ (2000) Commercial timbers: descriptions, illustrations, identification, and information retrieval. Version: 4th May 2000. http://www1.biologie.uni-hamburg.de/b-online//wood/english/index.htm.

Rozas V (2005) Dendrochronology of pedunculate oak (Quercus robur L.) in an old-growth pollarded woodland in northern Spain: tree-ring growth responses to climate. Annals of Forest Science 62: 209-218.

Rozas V \& García-González I (2012) Too wet for oaks? Inter-tree competition and recent persistent wetness predispose oaks to rainfall-induced dieback in Atlantic rainy forest. Global and Planetary Change 94-95: 62-71.

Rozas V, Camarero JJ, Sangüesa-Barreda G, Souto M \& García-González I (2015) Summer drought and ENSO-related cloudiness distinctly drive $\mathrm{Fa}$ gus sylvatica growth near the species rear-edge in northern Spain. Agricultural and Forest Meteorology 201: 153-164.

Sala OE, Chapin FS, Armesto JJ, Berlow E, Bloomfield J, Dirzo R, Huber-Sanwald E, Huenneke LF, Jackson RB, Kinzig A, Leemans R, Lodge DM, Mooney HA, Oesterheld M, Poff NL, Sykes MT, Walker BH, Walker M \& Wall DH (2000) Global biodiversity scenarios for the year 2100. Science 287: 1770-1774. 
Sánchez de Dios R, Benito-Garzón M \& Sainz-Ollero H (2009) Present and future extension of the Iberian submediterranean territories as determined from the distribution of marcescent oaks. Plant Ecology 204: 189-205.

Santini M, Collalti A \& Valentini R (2014) Climate change impacts on vegetation and water cycle in the Euro-Mediterranean region, studied by a likelihood approach. Regional Environmental Change 14: 1405-1418.

Scharnweber T, Manthey M, Criegee C, Bauwe A, Schröder C \& Wilmking M (2011) Drought matters - Declining precipitation influences growth of Fagus sylvatica L. and Quercus robur L. in north-eastern Germany. Forest Ecology and Management 262: 947-961.
Sperry JS, Hacke UG \& Pittermann J (2006) Size and function in conifer tracheids and angiosperm vessels. American Journal of Botany 93: 1490-1500.

Tardif J, Brisson J \& Bergeron Y (2001) Dendroclimatic analysis of Acer saccharum, Fagus grandifolia, and Tsuga canadensis from an old-growth forest, southwestern Quebec. Canadian Journal of Forest Research 31: 1491-1501.

Urban O, Janouš D, Acosta M, Czerny R, Markova I, Navratil M, Pavelka M, Pokorny R, Šprtova M, Zhang R, Špunda V, Grace J \& Marek MV (2007) Ecophysiological controls over the net ecosystem exchange of mountain spruce stand. Comparison of the response in direct vs. diffuse solar radiation. Global Change Biology 13: 157-168. 